\title{
IN THE BEGINNING THERE WILL HAVE BEen VIOLENCE: JUSTICE AND LAW. THE BROTHERS KARAMAZOV BY FYODOR DOSTOEVSKY
}

\author{
Milena Vladić Jovanov, University of Belgrade, Faculty of Philology, \\ Department of Comparative Literature and Literary Theory, \\ milena.vladicjovanov@live.fr, milenavladicjovanov@fil.bg.ac.rs
}

Original scientific paper

DOI: 10.31902/fll.38.2021.7

The realistic novel "The Brothers Karamazov" raises critical questions about modernist poetics, which refer to questions of religion, justice, law, and order within the narrative. They are interpreted both on the universal and the individual conceptual level, making the novel a complex system of narrative sequences. In the sequence related to the character of Ivan Karamazov, questions of fiction within fiction, writing and creation, repetition of the roles of the author and spectral characters in the story and the character of Ivan Karamazov are raised. These questions are modernist-critical and it is the intensity of their appearance that is referred to here. Modernism establishes the problematic situation of art itself, placing in the form of a meta quality, not only the question of artistic quality but also the field it belongs to in the foundations of the works of art themselves. The question raised is rooted in the basic meaning of literature. Literary forms bend self-referentially towards themselves, in order to twist anew and express reality. Modernist works ask readers whether all literary themes are legitimately literary or whether literature can deal with "any" topic. These questions have arisen since art has self-referentially bent towards the entirety of culture and art, and all the various questions raised in specific scientific fields. Therefore, it is sometimes said that literary works are, for example, philosophical, psychological. However, that refers to the entire literary order, whereas in the stated narrative the questions are so complex and the question of the literary status itself is entwined with their complexity.

Kewords: multiplicity of narrative structures, discursive strategies, interweaving of structural-semantic-linguistic levels, fiction within fiction, monolingualism, aporia, self-referentiality, spectral characters, forgiveness, sin, redemption, law and justice, identity of the individual, character, narrative. 
They that have power to hurt and will do none, That do not do the thing they most do show, Who, moving others, are themselves as stone, Unmoved, cold, and to temptation slow:

They rightly do inherit heaven's graces And husband nature's riches from expense; They are the lords and owners of their faces, Others but stewards of their excellence.

The summer's flower is to the summer sweet

Though to itself it only live and die, But if that flower with base infection meet, The basest weed outbraves his dignity:

For sweetest things turn sourest by their deeds;

Lilies that fester smell far worse than weeds.

(Shakespeare 762)

Albert Einstein once said that politics is much more complicated than physics. In The Brothers Karamazov novel, a special kind of physics, but also politics, is encountered. Physics deals with natural phenomena and the laws of the same, with experiments and proofs. There is a kind of naturalness and law in the novel, perhaps not directly from the field of physics, but from life as a natural phenomenon. At the heart of this narrative is a detective story that, as a pattern, can intertextually extend to many of Dostoevsky's novels and create a kind of network. As Aristotle states in "Physics" (Aristotle 184a), in any research in which there are principles, causes or elements, knowledge and cognition follow from knowledge of given laws. In this narrative, the existence of a law is certain and it manifests in two forms: the asking of questions about the legitimacy of the work of art, and the origin of the law of religion itself and the law as such, which is given on a thematic level. Although the majority view is that psychological-philosophical-religious elements are the strong suits of this novel, it will be pointed out that they have a rather double status in the novel itself: they can be viewed as present, but also as separate, external parts of the novel. In the "Mutiny" and "The Grand Inquisitor" chapters, for example, Dostoevsky does not present an individual societal image according to the rules of realistic poetics but turns the mirror of Christian civilization towards the reader of any age. Their status instructs towards thinking about the artistic status of the narrative which carries fiction within fiction. At the same time, he raises questions about writing fiction and, by writing as such, about topics that appear as topics on multiple levels and belong to 
other, as a rule, non-literary areas. Therefore, in this novel politics can be discussed from the contemporary point of view of studying a literary work. The policy of this novel is to problematise the issue of different conceptual nuances in understanding the concept of individual identity in society and religion, the identity of religion itself and the laws it is based on, and simultaneously the laws on which the sciences that have had their elements discussed in the form of a structural-semantic entwining are based.

I

\section{Violence - "Just and true art Thou, O Lord!"}

Today's perception of the interconnectedness of literature, politics, religion, philosophy, etc. guides towards a thorough pondering of the questions posed by the doubled fictional subject - the character of Ivan Karamazov. He is simultaneously a character, as well as the writer of "The Grand Inquisitor" poema. Problematising the issues of the Christian religion and society as a whole, Ivan Karamazov answers questions about his own identity. In their being problematised he finds an inward path to himself. One of the initial premises of Ivan's thinking is the law of violence in religion. Ivan Karamazov does not only talk of the inadmissibility of violence in religion but also of the law of violence, which as a law annuls its own legislative right as its basis because the law on violence as a law is not applied at all. When he expresses that the harmony of the Christian faith cannot be based on children's tears, Ivan Karamazov says that there is no law on violence and that religion itself is based on the opposite belief - on non-violent behaviour, kindness, and forgiveness. Ivan Karamazov raises the question of the presumed unique origin of religion, whose cracks are precisely different forms of violence, which is most painfully, yet most provocatively, expressed in the suffering of children.

Look: if everyone must suffer in order with their suffering to purchase eternal harmony, what do young children have to do with it, tell me, please? It is quite impossible to understand why they should have to suffer, and why should they have to purchase harmony with their sufferings? Why have they also ended up as raw material, to be the manure for someone else's future harmony? [...] Oh, Alyosha, I do not blaspheme! And I understand what a shaking must rend the universe when all that is in heaven and under the earth flows together in one laudatory voice, [...] when the mother embraces the torturer who tore her son to pieces with his dogs, and all three of them proclaim in tears: "Just and true art Thou, O Lord," then, of course, the day of knowledge will have dawned and all will 
be explained. The only trouble is that it's precisely that I cannot accept. [...] I shall hasten to guard myself, and so I decline the offer of eternal harmony altogether. [...] It is not worth it because its tears have remained unredeemed. They must be redeemed, or there can be no harmony. But by what means, by what means will you redeem them? Is it even possible? [...] I want to forgive and I want to embrace - I don't want anyone to suffer any more. And if the sufferings of children have gone to replenish the sum of suffering that was needed in order to purchase the truth, then I declare in advance that no truth, not even the whole truth, is worth such a price. (Dostoevsky 187)

Ivan Karamazov, within the question of origin, raises the question of cognition and responsibility as part of the cognitive process, of forgiveness as an impossible act, which has no feedback loop because the suffering of children cannot be redeemed, nor can time go back. Nevertheless, forgiveness is discussed and impossible questions are given possible answers by creating a literary work as a possible answer to these aporias. It needs to be noted that the question of the origin of religion can be observed from several standpoints. The text itself associatively directs towards the linguistic level. The word "material", that the children had got into, is brought up, and whether such a truth is worth such a "price". The linguistic level leads towards interpreting religion and harmony as a kind of administrative order similar to the scene from Mike Nichols' TV miniseries, "Angels in America", in which angels are officials who flip through papers of recorded sins, forgiveness, and so on. In the pile of papers, a paper crucial for human identity and the existential dread that each individual goes through could be lost. Paperwork introduces one to the material that has a price list - to an economy where the law of giving is treated as the law of taking and returning. "The Grand Inquisitor" poema would be a poem about economics whose documentation the inquisitor carefully keeps. Therefore, the chapter on rebellion is necessarily followed by the poem. However, the before and after within the text could textually be displaced, hence the rebellion could easily come second because in the beginning there is order, hierarchy, and not a presupposed unity. The presupposed unity could be reflected in a presupposed unique language which, as the biblical language, would not be prone to interpretations, but would be clear to everyone immediately. Everyone would understand the language without question. That type of monolingualism would be the opposite of the Tower of Babel that the Grand Inquisitor wants to complete. However, the language or 
languages of the Grand Inquisitor would just be another type of monolingualism. It needs to be asked: does monolingualism as such really exist? "I have only one language; and it is not mine. [...] I am monolingual. My monolingualism dwells, and I call it my dwelling; it feels like one to me, and I remain in it and inhabit it. It inhabits me. The monolingualism in which I draw my very breath is, for me, my element. Not a natural element, not the transparency of the ether, but an absolute habitat. It is impassable, indisputable: I cannot challenge it except by testifying to its omnipresence in me. It would always have preceded me. [...] For me, this monolingualism is me. [...] It constitutes me, it dictates even ipseity of all things to me, and also prescribes a monastic solitude for me; as if, even before learning to speak, I had been bound by some vows." (Derrida 1-2). It is interesting that the house in which the individual whom Derrida mentions lives is not actually his, even though he is defined by everything that belongs to that house and home. Essentially, this kind of linguistic space would be the kind of biblical speech that requires everything to be understood without anything having to be explained. There is no commentary in the biblical text. The fiction of the biblical text is based on interpretations. It is even more interesting that the biblical language of both brothers, the Christian-minded Alyosha and the inquisitive Ivan, actually represent the "same" language, which is omnipresent and which determines the being even before the creation of its identity. This type of household is impossible, as well as undeniable and unutterable, which is why it cannot be talked about in the end, because speech implies changes and non-presence, that is, differences and absence. For Ivan Karamazov, this monolingualism is an aporia because it does not belong to him. Isn't monolingualism understood as such, something that is proper for Ivan and his features and property? It is not something that is his own and, therefore, he does not agree with it. In his eyes, that kind of speech is impossible and represents a kind of logic of contradiction - a lie that rhetoric takes a loan of on its own account. Ivan Karamazov notices that he has found himself in the aporia of language and identity. Such a language without justification, without explanation, without indication, without distinction is not accepted seeing it cannot express the suffering of the innocent. It cannot be explained in a humane way why the innocent suffer when they have no sin, even when referring to the idiomatic sentence "Just and true art Thou, O Lord!". Moreover, the same cannot be explained for why Abraham must or agrees to sacrifice his son Isaac, tearing apart his own identity and any kind of previous belief, and, at the same time, bringing in question God's promises of Isaac prolonging his lineage. Just as Abraham is in the aporic space of 
identity, so is Ivan in the aporian space of language that influences and largely defines his identity. A question arises as to whether Ivan and Alyosha converse or just intrude on each other's property of a language that is not their own. Alyosha's faith is no stronger than Ivan's reflections on faith. Alyosha's and Ivan's language manage to establish a contradictory relation in inter-communication, but a relation of one language to another nevertheless. Their contradiction takes the form of a law. The law is, much like religion, fundamentally contradictory. Undecidability of which path to take when the origin is doubled, i.e. when it is not singular, marks the notion of identity as belonging to anything, in this case a language that expresses the deepest belief in salvation and forgiveness and, at the same time, questions it. If language is always the language of another, then monolingualism does not imply the meta qualities of language that Ivan is in desperate need of. In the biblical language that implies a unique origin, Ivan does not find a metalanguage that would, for such a language, be "the absolute impossibility of metalanguage. The impossibility of an absolute metalanguage, at least, for some effects of metalanguage, effects or relative phenomena, namely relays of metalanguage 'within' a language, already introduce into it some translation and some objectification in progress. At the horizon, visible and miraculous, spectral but infinitely desirable, they allow the mirage of another language to tremble." (Derrida 22). Ivan Karamazov is in need of a metalanguage in order to be able to make an objection to the all too simply understood metalingualism. The metalanguage within a language, as Derrida states, is miraculous and spectral, which means that it needs a mirror image and a cross-section of the image that is created in the reflection and reflecting rays. Contemporaneously, spectrality would be a feature of literature. Spectrality manifests, as Derrida states in his essay "The Law of Genre" in "The Acts of Literature", in the form of a spectral image of the father in F. Kafka's "Letter to the Father" and represents, in fact, a possibility of creating fiction within fiction since spectrality is precisely reflected in the possibility to open the field of literary language and of literature that would answer the questions of the impossible by showcasing its way of being made. Spectrality and mirage also appear in Dostoevsky's work where another language trembles, but not the language of literature, rather the relations between the literary and the social language. The polyphony observed by M. Bakhtin in "Problems of Dostoyevsky's Poetics" can refer precisely to this type of relation that opens the space between one voice that perceives another voice in itself. Nothing is inherent or belonging, but the relation between the elements as one of the constitutive factors of the literary is always 
present. Repetition and the mirror relation introduce the problematisation of substitution and protection in the sense of aporia, which Derrida connects with the original Greek origin of the term. "The word 'aporia' appears in person in Aristotle's famous text, Physics IV (217b) which reconstitutes the aporia or time dia tōn exoterikōn logōn. [...] the short text that, twenty-five years ago, I devoted to a note on time in Being and Time ("Ousia and Grammē: Note on a Note from Being and Time", in Margins of Philosophy) [...] treated the question of the present, of presence and of the presentation of the present, of time, of being, and above all of nonbeing, more precisely of a certain impossibility as nonviability, as nontrack or barred path." (Derrida 13). Given are the concepts that can be connected with the identity of the character of Ivan Karamazov and with the origin as the source of the identity of religion. They all relate to aporia as a state, as well as a space in which one cannot go further. The notions of time, presence, being and non-being, the impossible, are interconnected, and in their connectedness, in fact, represent the fabric of this part of the narrative that appears as a mirage, as an image - as a spectral identification of the larger narrative of "The Brothers Karamazov", but in such a way that the images are reflected in one another. Can the law of this text be noticed? Ivan does not want to accept the uniformity of language, which is reflected in the uniformity of faith that, instead of the essence, puts protection and a substitution up front. Law can be interpreted as the law of fiction, as the notion of the origin of law, as the notion of legality, as well as the law of language. The biblical language interpreted in Ivan's way leaves no room for metalanguage and reflection, representing the law of language without its essence, which is why Ivan rebels. However, as he himself notes, one cannot live off of rebellion. One must act. Even so, Ivan fails to act on his own, and his identity, as it is being created, actually shows the self-awareness that Ivan comes to in the fact that he is not capable of committing the crime he "preaches" about - the one which Smerdyakov does in his place. Law exists as a law of language and a law as a language, both of which are found in this text. There is a duality in law itself, hence Ivan cannot accept the onefoldness since the only way of accepting it would be to dismiss statements without explaining and understanding the cracks of the law as a language whose cracks are, precisely, the redemption of children's tears and forgiveness belonging to the notion of the impossible, because the murderer and the murdered must look at and meet one another in order for forgiveness as something between the two to be possible and to have a chance at functioning. Otherwise, if there is no way back, in forgiveness one is always met with mediators - be they abstract, from an 
interpretation, to mediators in legislative law such as lawyers, the court, and the like. Derrida states that the experience of the duality of law is, on the one hand, autonomous, while, on the other hand, heterogeneous, with the way back being noticeable in relation to the subject. In this sense, the origin of the law shifts beyond itself. "Its experience would be ostensibly autonomous, because I have to speak this Law and appropriate it in order understand it as if I was giving it to myself. But it remains necessarily heteronomous, for such is, at bottom, the essence of any law. The madness of the law places its possibility lastingly [à demeure] inside the dwelling of this auto-heteronomy." (Derrida 39) Autonomy comes when one observes oneself from a different perspective, through the eyes of another. The autonomy of the origin of religion has a double of origin. Whichever way is chosen to be taken, the other one gets erased. In one of his "Heretical Essays on the Philosophy of History", Jan Patočka notes that in addition to the rational, there also exists an irrational side to the origin of religion, and this origin is related to the forming of responsibility in the individual which he connects with consciousness, self-awareness and conscience. In itself, it carries the origin of the gathering of individuals that has both a sacred and a mysterious aspect to itself, with the sacred being, in fact, a demonic sacralisation, which is orgiastic, irrational, esoteric, mysterious and so on. By overcoming this aspect, the individual forms a responsibility that does not imply the demonic in any form. However, Patočka explains that even Husserl and Heidegger, on the contrary, perceive the phenomenon as a problem rather than a pure form and in their attempt, particularly in Husserl's work, they try to explain the phenomenon from different perspectives, finding linguistic and conceptual ways of getting out of the problem situation. Husserl tries to bring the materiality of the voice, which is at the lowest level, closer to the signified, and to erase the materiality of the signifier as a voice, thus fulfilling the presence and unity of the signifier and the signified. Through his understanding of the event (Ereignis) and of its experience, Heidegger notes that the event is affiliated with and belongs to the Being (Sein), but in the eventfulness and temporality, that occurs between the being $D a$-Sein and Sein the existence of Da-Sein and of its existential and phenomenological problems is made possible, as well as of the Being (Sein) into which the experience of Da-Sein is entangled. Heidegger interprets belonging and corresponding belonging, trait and corresponding trait in a linguistic way, concluding that it is not the event but from the event, meaning that something originates and belongs to the event that transfers its belonging onto Sein and Da-Sein. The transcendental question of time and the new existential analysis of Da- 
Sein temporality was the most acceptable framework for re-elaborating the question of time. This movement was shifted in the opposite direction, towards a reorientation, a reversal - to 'the turn' (die Kehre). The question of being on that path is not subordinated to the question of Ereignis. Ereignis is a term and a word that usually denotes an event, or either an addition or non-addition that is related to Enteignen. Ereignis and Enteignen are not in binary opposition of the or/or type, but rather of the and/and type. It is, once again, a matter of a mutual conditioning, as it is in the mutual relation of the gift and of absolute oblivion. The temporality of Da-Sein presented a new horizon for reexamining the question of Being, which is now turned towards the event and non-attribution and can be connected with the notion of the gift as Derrida had interpreted it. Thence, the structure or scheme that has presented itself is the connecting of several concepts: Being, being, time, event - either an attribution or non-attribution, both of which cannot be separated and are closely related to the gift. The Being and the gift are conditioned by each other. Heidegger even states that the Being is Ereignis. Therefore, a Being that is not present presencing or presencing present is conceived based on the gift. Derrida goes a step further and ponders the question of the gift on a linguistic level. The German expression es gibt appears in Heidegger's Sein und Zeit. Idiomatic locutions es gibt Sein, as well as es gibt Zeit, are translated as "it gives Being" and "it gives time", and not as "it is Being" and "it is time". With the copula "is", or rather "it is", a certain element that ought to be excluded is included - the temporality of time that has been reduced to the "present now". Derrida states that "Heidegger tries to get us to hear in this the 'it gives'." (Derrida 20) It is not a kind of binary opposition since the focus is on "it", as well as on "gives". In his book Sein und Zeit, Heidegger's attention is turned towards the verb to giveto giving (Geben) and gift (Gabe) which are implied in es gibt. Heidegger always notes that time in itself is not temporal because it is nothing, since it is not a thing (kein Ding). It is similar to the Being - neither is it a being in the sense of the present being and its presence, since it is not a thing (kein Ding). This is the reason for es gibt Sein and es gibt Zeit being used and for it is being and it is time not being possible. Therefore, Heidegger proposes using the word Sache and not Ding so that it is neither a being, nor a thing, nor an object, nor a temporal thing. Heidegger, practically, connected and conditioned the existence of Being and time, believing that they exist in relation to each other and that both are "products" of the gift. In the translation of the aforementioned expressions - it gives Being or it gives time, and not it is being or it is time - Heidegger managed to connect the it gives, 
through a careful reflection, with the expression "that or it that gives". It (es) gives time and being, giving them to each other because of their being held together in relation to each other. In other words, if time and Being are conditioned by a gift, and the gift itself is based on the relationship of establishment and annulment, on an oblivion that is not psychological or any other type of it, but rather absolute, meaning that it is temporally annulled but also existing, whereas in the being's case it is annulled, meaning that neither Being nor time owe anything to each other, but are conditioned by each other, in other words, by giving. However, it ought to be noted that by substituting Ding with Sache, Heidegger raised the question of property and uniqueness of both time and Being connected by the notion of the gift. This is possible only if es gibt is left to experience (erfahren) and perception (erblicken). What is that which is in that which is being given? In asking such a question, it would do good to think upon the property of Being and time, while Heidegger, as has been shown already, notes that the property is already determined by the dimension of giving or, rather, by the gift. It is important for the story about Ivan Karamazov, who is in a state of his own exile, to be noted that the issues of time and Being, which are in relation to the gift, which is, again, in relation to the event and attribution or subtraction - non-attribution - which is, practically, a movement, are tied with verbs in grammar, while in the story they are tied with the structure of the narrative itself, leading to their being properly emphasized and noting that everything is connected with experience and perception. The event is connected with experience. Without the event, the story does not exist, and it does not exist without the experience of the event which is practically part of the reading process. At one point Heidegger says that the truth of Being is in the event. "Dieses Ereignis ist die Wahrheit des Seyns." (Heidegger 27) It should be noted that das Seyn is an archaic spelling, which Heidegger uses to invoke a remembrance of words in a thoughtful way (denkerisch). Derrida points out:" What would it mean to think the gift, Being, and time properly in that which is most proper to the or in that which is properly their own, that is, what they can give over to the movements or propriation, expropriation, de-propriation or appropriation? Can one ask these questions without anticipating a thought, even a desire of the proper? A desire to accede to the property of the proper? Is this a circle? Is there any other definition of desire? In that case, how to enter into such a circle or how to get out of it? Are the entrance and the exit the only two modalities of our inscription in the circle? Is this circle itself inscribed in the interlacing of a Geflecht of which it forms but one figure? There are so many threads to be 
pursued." (Derrida 21-22). Ivan Karamazov cannot enter the circle, nor can he get out of it. He does not want to deny that he belongs to something, but he cannot accept the way he must belong. He cannot accept the forgiveness that is part of the order, and therefore he cannot accept the order either. He returns the entry ticket for such a circle since the ticket is too expensive. To whom or what should Ivan Karamazov belong? Who should he answer? Who asks him questions? Although he wants to belong both through that belonging and his identity, Ivan is still in the field of aporia on the linguistic, as well as on the religious and philosophical level. What he can do - to put his idea, which is based on a binary opposition, "if there is no forgiveness", then "everything is allowed" into action - he cannot do alone. He needs someone else to carry out that idea. In the fiction itself, there is a twist. Dostoevsky described the given approach and its execution in a rather literary language and self-referential way. To his brother Alyosha, Ivan Karamazov looks like someone who leaves with his shoulder bent to the left, symbolically to the devil's side. Nevertheless, the one who commits the crime itself is Smerdyakov who does not look like the devil at all and who, on the contrary, has Christian writings on his desk. What can semiotic readers infer from this? The literary educated readers are pulled to the side in a form of metafiction or, even, their literary knowledge by the author. Ivan Karamazov, regardless of the story - of the fiction in which the role of the author is doubled - cannot realize and implement his ideas into action. In other words, the character of Ivan Karamazov cannot be interpreted through the lens of a Faustian motif, nor any motif related to the demonic or fantastic. Ivan does not belong, yet he wants to belong. He is trapped in a circle which he cannot get out of nor can he enter. Ergo, his understanding of forgiveness has been withheld. Forgiveness does not come, because not only does Ivan not reject the idea of forgiveness in the universal Christian harmony that will come, but he also refuses to forgive himself and others. In terms of fiction, this is used to build fiction within fiction, because the questions posed by Ivan Karamazov withhold the event as well. The event is halved in this narrative. One half belongs to the narrative and structural line carried by the story of the Karamazov family, the rape of a small-minded woman, the murder of the father, the theft and the like, while the other half, which is being led by the event outside the narrative, is the story that consists of Ivan's inner narrative that is spectrally given in relation to the main narrative. Is there a central event that constitutes the whole narrative? The event of Ivan's inner narrative is a meditation on the event - his reasoning and speculation on religion, identity, forgiveness - which can go on infinitely. Is the event in structured layers of the 
narration, in the relation that links the narrator to himself, that which urges him to ask himself what is happening to religion, to history, and at the end what is happening to himself? Who is being forgiven? Who forgives? Why do they forgive? When do they forgive? Virtually, all questions raised that are simultaneously put into relation not only to fiction but also to the position of religion as an order that turns in the speech of the Grand Inquisitor into a speech about the economic order based on inequality and governance, and the management of the idea of freedom - of freedom in the form of irresponsibility and ease. For the reader, the question being asked is what is happening with this story with this narrative? If this narrative relation is thought of as a link, as a movement which is the event, then the same link would be found in religion. What is happening is always between them - between one and the other - and at the same time that which manifest the form is the form of the narrative relation as such and to itself. Following Patočka's thought, Derrida states that "In the proper sense of the word, religion exists once the secret of the sacred, orgiastic, or demonic mystery has been, if not destroyed, at least integrated, and finally subjected to the sphere of responsibility. [...] Religion is responsibility or it is nothing at all. Its history derives its sense entirely from the idea of a passage to responsibility." (Derrida 2). Does Ivan Karamazov manage to find a way towards responsibility? Is the history of religion at the same time part of the history of his identity? What Ivan Karamazov refers to is that in the form of a religious order, forgiveness understood in such a way that the violence-doer and the one who suffers violence reconcile with and understand one another is, in fact, not part of the responsibility. In other words, violence is present much like in language, in the basis of religion, as well as all the concepts related to religion, religious thought, and faith, such as the concepts of good, justice, forgiveness, unification, sin, redemption, etc. All of them are connected by the umbrella concept of gift, which is, again, a structure for the substructures of forgiveness. The concept of justice is mentioned in Ivan's story, which is connected with the concept of law. Put differently, another "illegitimate" discipline has entered Ivan's story and it does not destabilise it, but rather, on the contrary, opens it to the question of the very status of fiction which must be brought up anew.

\section{II}

\section{Justice and Law}

Law has no unique origin. It is universal, but it is applied with regards to interpretations, and individually. In its being defined, the closer it gets to its essence, universality, and equality for all, the more it 
loses its essence. Its constitution erases its own constituency. Namely, the position of law is twofold and reversed, which follows the timeline. The second comes before the first. What comes after defines what comes before, which also affects the causal relations of cause and effect. Interpreting the notion of the origin of law in the book "Acts of Literature" Derrida, following in the footsteps of Freud, suggests that the moral law of the horde in the human community points precisely to this kind of duality in the origin of law. In his work "Totem and Taboo" Freud states that the sons killed the tyrant father, but after having done so, they did not take his power and the father's privileges for themselves. They banned this act. Therefore, the law came from a violation, after and before its establishment and functioning. Moreover, the sons were overwhelmed by tender feelings, which points to irrational moments that one must be freed of or subdue them on the way to any form of responsibility. The dead father, therefore, begins to live much longer and rules both through conduct and feelings, by law which is being more so enforced than any law was while he had been alive. In the history of both religion and law, it needs to be started from everything other than a clear starting point, and Ivan Karamazov seeks clarity because he cannot meaningfully understand the forgiveness that belongs to the realm of the im-possible. He wants to make the impossible possible by acting, but his actions only cause disorder in him. What makes the impossible possible is precisely the literary explanation and the fiction that is deeply involved in what is not its area - religion and law - with it being presented twofold as fiction within the wider fiction - within the narrative of The Brothers Karamazov. Is forgiveness in relation to the event and does it represent a path to understanding Sein and Da-Sein? The entire economic exposition of the Grand Inquisitor is Ivan's narrative of justice and law in a religion that allows violence. The Inquisitor reduces existential problems to the problems of survival, handing over one's conscience to another and unification. While answering these questions, a new one - the question of the character of the Grand Inquisitor - arises on a fictional level. The reader is not addressed by a character from the narrative about the Karamazovs, but rather by a character whom a character invents. The narrative sequence, in this case, could be questioned since the relation between the characters rests on a symmetrical necessity. Alyosha exists only as Ivan's brother, and not as an individual who is not related to Ivan or his brother Mitya. In other words, the narrative sequence is based on their pre-determined relations. The character of the Grand Inquisitor has no relations within/to the narrative, so here, too, is a case of fiction within fiction or a shift of fiction(s). The basis of the character of the 
Grand Inquisitor is not symmetrical, but one of the relations of his story is the mirror relation and a relation at odds with the laws of the logic of mimesis. How this triple fictional status is now observed is: through dialogue and through repetition. The Inquisitor does not talk to Christ, but to himself and thus takes fiction out of fiction because the image of Christ is exactly the inverted image of the Inquisitor. Conversely, it is not a dialogue with Christ that he has, but with the entirety of the Christian civilization and culture. The image of Christ does not even answer the Inquisitor's repeated question as to why he came just then to bother them when they had already organized everything. The repetition of this sentence divides the narrative into several parts that are constantly thematically being repeated and address questions and objections to the religious system as the Inquisitor sees how Christ had conceived and preached it. In repeatability, spaces are opened in which the answers that the Inquisitor leaves are hinted at and remain open to interpretation.

Oh, we shall persuade them at last not to be proud, for you bore them up and by doing so taught them to be proud; we shall prove to them that they are feeble, that they are merely pathetic children, but that childish happiness is sweeter than all others. [...] Oh, we shall permit them sin, too, they are weak and powerless and they will love us like children for letting them sin. [...] We shall tell them that every sin can be redeemed as long as it is committed with our leave; [...] It is said and prophesied that you will come and prevail anew, will come with your chosen, your proud and mighty ones, but we will say that they have saved only themselves, while we have saved all. [...] You may as well know that I too was in the wilderness, that I too nourished myself on roots and locusts, that I too blessed the freedom with which you have blessed human beings, I too prepared myself to join the number of your chosen ones, the number of the strong and the mighty with a yearning to 'fulfil the number'. But I come to my senses again and was unwilling to serve madness. I returned and adhered to the crowd of those who have corrected your great deed. (Dostoevsky 196-197).

In other words, the question of spectrality within fiction arises - of spectrality that is part of the problem setting of the origin. Christ enables the origin of the Inquisitor and his story, which is based on the appearance but also on the preaching of Christ. Ivan's character is in a story that is given as fiction within fiction, as a poem, which has its own preface - the dialogue of Alyosha and Ivan, based on the character of the Inquisitor who is spectral and somewhat apparitional in relation to 
the "reality" of Ivan's character. As a result, spectrality is only repeated and multiplied in these mirror images and reflections. This type of narrative structure reveals that Dostoevsky, as a realistic writer, is virtually on the threshold of modernism. As is the case for a large number of modernists, he reveals to his readers only the experience of writing narratives - of writing artistic prose. In this experience, he reveals to his readers, through hints or symptoms that they have to follow on their own like threads of a great weaving, how the work of art was created. Shedding light onto one's way of writing is a metaquality, which is typically modernist because it is hidden in semi-darkness, with only one part of it being illuminated. Reader participation is always required to discover it. Dostoevsky reminds his readers that he is not only a realistic writer but that he is a writer who understands realism somewhat differently. The poetics of Russian writers, both in the XIX and in the XX century, is not nearly the same as the Western poetics of writers of similar prose works. Russian writers always shine some special light on the poetics they use in their approach. That light is like a lamp on a table, individually speaking, yet it also has the general characteristic of a central light that illuminates everyone who sits at different tables. On the one hand, Dostoevsky pulls the reader by their sleeve with his authorial comments, warning them, like Balzac, to stop and examine the characters in the novel, and on the other hand, he makes realism that leads the reader through fiction within fiction and metaqualities into modernist poetics possible. Lev Nikolayevich Tolstoy did the same when, in the story titled "A History of Yesterday", he added traces of what would later become known as the stream of consciousness novel into the inner monologue. It would do good to return to the event and its relations in the mediation of meaning between Sein and Da-Sein, in the Heideggerian philosophical way, as well as in a fictional, artistic way for a moment. It would be best to stop here if one is to connect that which is hidden or protected and the aporia should come to mind again. Within the aporia itself, the concept of the problem is connected - a problem situation that signifies two important concepts in deconstruction, namely replacement and protection. It is in this that what is hidden appears; and that which is hidden is, if Patočka and his path toward selfawareness and responsibility are recalled, precisely the demonic that must come out into view. Predominantly, in time and in Being both, there is another side that is not present, which is invisible and hidden, which is mysterious, and which remains visible as a secret even though it is a secret. The presence of Being and time is no longer as important as the secret and the hidden and protected is. The structure in question has a substructure - the substructure of one basic structure of desire: 
forgiveness. That which gives time and Being is revealed precisely in its retreat when that which is hidden and protected appears. This is the field of the im-possible and of the aporic since substitution is used as a means of protection, making this Platonic problem not solvable. Heidegger also states that this confusion of the game manifests the unity of the three dimensions of time that announces the fourth dimension, which is precisely reflected in giving. It is precisely this giving that is the peculiarity of time. That which is es gibt has the peculiarity of the gift itself. The gift is a peculiarity for both Being and time. Fourdimensionality is a property in es gibt Zeit. Heidegger states that the property of time or essential time is four-dimensional, meaning that it is not just a way of speaking, but rather an object of time (aus der Sache) or that it implies a game of four or a game of gifts. The game or the adding, changing, and moving that the game implies evoke the event as Heidegger sees it. Being - Sein - and being, presencing - Da-Sein virtually meet in the event. It is not a typical form of event, which is used to describe what has already happened, but rather that which moves things and is future-oriented. That is why the event in Heidegger is connected with time and temporality. Literary scholars find the inclusion and comparison of the event defined as such in philosophy with the basic meaning of the event in literary theory interesting, hence what Heidegger writes about the event at the very beginning of his book "Contributions to Philosophy (Of the Event)", in which he deals with the notion of the event, ought to be mentioned. "Future thinking is a course of thought, on which the hitherto altogether concealed realm of the essential occurrence of beyng is traversed and so is first cleared and attained in its most proper character as an event. The issue is no longer to be 'about' something, to present something objective, but to be appropriated over to the appropriating event. That is equivalent to an essential transformation of the human being: from 'rational animal' (animal rationale) to Da-Sein. (Heidegger 5). Heidegger points out that the appropriate title is, therefore, Of [von] the Event, where he thinks and in German emphasizes linguistically precisely Vom Ereignis. It is, thus, a syntagm of an event, not an event, meaning that in a literary sense it is not something that is retold, which accounts are written on, but something completely different: something that is originating and belongs to Being, that is caught hold of by the event. In Of [von] the Event, through contemplation it is pointed towards belonging to Being and in the very word Da-Sein, to the presencing. The essence of Sein is in the process of its originating and is revealed by reflection which includes the event. Without the event, the essence of Being cannot be reached, and all of that belongs to and is expressed through and in the 
word des Seyns, i. e. Da-Sein. Heidegger notes the difference between the first beginning and the reflection he is talking about. The reflection is not made simply because of it being different from other philosophical approaches, rather it is the only other beginning that must sprout in relation to the first and only beginning. The relation between the presencing and Being in relation to the event and the essence of presencing and Being is key. The essence of both is located in the inbetween, that is, in the event that divides Being and the presencing. The event occurs between them and is appropriated by the Being whom that appropriation belongs to, but who is, at the same time, appropriated by the event. Hence, Heidegger states that the better name for Contributions to Philosophy (Of the Event) is precisely Of [von] the Event and not of the Event. In the story between Abraham and God, the key that defines the corresponding essence is the event - the binding of Isaac, of course. The idea of Isaac being sacrificed, followed by Abraham's response to that idea, leads to a narrative sequence in which the sacrifice does not take place, defining the self-consciousness of the individual, the essential, of that which is on earth - Abraham - and simultaneously defining the belonging to the Being appropriated by the event. It gives a transition, a passage, and a constant emergence of the essence. In other words, there is no absolute truth, rather it is in the emergence, change, transformation. Therefore, Heidegger states that historical thinking is important. Here its importance lies in its pointing towards Christianity not only as a faith but also as a civilization. Contemplation is transitional, making it possible for it to achieve a basic projection of the truth of Being as a historical meditation. What poses a problem in Ivan's search for his own identity is precisely his nonacceptance of identity as a search for and a discovery of differences. In terms of how humans think, one mode of thinking would be intellectual thinking, in which humans break things down into elements and then assemble them, and another would be visionary thinking when things are clear to humans even before their being broken down. Be that as it may, Ivan Karamazov does not accept this particular truth. In that nonacceptance, he is something reminiscent of Ovid's Narcissus who, looking at his own image and not being able to reach it, does not accept its difference from himself and thus dies. Ivan cannot reach out to the image he believes to be the right one, nor can he make the "order" he had envisioned in reality. He is in a hurry to protect himself and to find a replacement for his ideas - for the truth he aspires to. However, the truth he aspires to is as im-possible as the life of Ivan Karamazov. He does not accept his identity in the search but in the absolute - in a binary opposition or/or. He offers forgiveness but does not accept it, so he is in 
the field of not only the aporic but of the im-possible. If redemption is possible, then there is sin, but Ivan Karamazov does not accept sin as such but rather defines it as the non-sin of the innocent. As a result, he falls into the abyss of aporia because only sin can be redeemed. If there is no sin, there is nothing that could be redeemed. Similar to Eliot's beginning in "Four Quartets (BN)". "If all time is eternally present / All time is unredeemable. / What might have been is an abstraction / Remaining a perpetual possibility / Only in a world of speculation. / What might have been and what has been / Point to one end, which is always present. / Footfalls echo in the memory / Down the passage which we did not take / Towards the door we never opened / Into the rose-garden. My words echo / Thus, in your mind." (Eliot 117). In Eliot's play on words, there is no eternal time, because time exists only if something happened in it and if what happened can be redeemed, if, of course, it had been a violation of sorts. There is also a logical reversal in the verses. Nothing can resonate on the passage that had not even been taken, just as there can be no eternal time that is constantly present and inexhaustible. In other words, an event that would connect eternity and temporality with the Being and its existence would have to be tied to the questions: Who? When? To whom? Why? Where? These questions are related to the notion of the event in fiction. In fiction, questions like who gave something to someone, to whom did they give it, who forgave someone, whom did they forgive, or why did they give something to someone and why did they forgive someone are all resolved - they are given answers to - and, perhaps, literature is the only way to make reflecting upon im-possible concepts through its forms and ways of creation possible to the individual - about im-possible concepts that are so close and familiar to each individual and, in general, to civilization thus enabling possibilities of survival in the more endless narratives of life. Ivan Karamazov remains in speculation - in abstraction - and when he acts, he does not do so alone. That is to say, he is in an intense state in which he neither accepts himself, nor does he accept others. He does not accept death as his absence, nor his image, nor the echo that remains behind him; repetition is difficult for him because he cannot merge with what he wants - with the image he imagined. However, in an attempt to realize his identity in nature, in reality, in society, he reaches for the concept which, in the case of the gift and of forgiveness, is the umbrella concept. Be it the gift and forgiveness, the event philosophically or narratively interpreted, the concept of an alliance unites the individual in their abstract, individual, yet human and universal thinking. The alliance is key since an alliance is formed with God, an alliance is formed with oneself, an alliance is formed with other 
individuals or groups. The alliance makes the survival of the human community possible. In the making of an alliance, the violation of the alliance has already been determined. Namely, although it represents an umbrella concept - a relational concept for many other concepts the concept of the alliance is already split in its essence. There is an alliance between the gift and forgiveness. Who gave what, or who forgave whom? A crucial concept for these two is the concept of the event, which is phenomenological, fictional, and ultimately philosophical. Having said that, it is twofold - it can connect the concept of the gift and forgiveness within time with time itself only through the gift in relation to the essence of Sein and Da-Sein. Ivan Karamazov does not come to a conclusion. Neither does he give, neither does he forgive, neither does he act, neither does he accept, neither is he accepted. In each of the forms, the events in relation to the character of Ivan Karamazov are such that they lead to the reader's careful examination of questions posed by the spectral character and the double author, which have tormented humans and their existence since times long past.

\section{Works Cited}

Abbott, H. Porter. The Cambridge Introduction to Narrative, Second edition. Cambridge: Cambridge University Press, 2008.

Allen, Graham: Intertextuality, London and New York: Routledge, 2003.

Agamben, Giorgio: Language and Death. The Place of Negativity.

Translated by Karen E. Pinkus with Michael Hardt. Minneapolis, London: University of Minnesota Press, 1982.

Aristotelis. Physica. W. D. Ross. Oxford: Oxford University Press, 1977.

Bakhtin, M. M. Problems of Dostoevsky's Poetics. C. Emerson. (trans. and ed.). Minneapolis MN: University of Minnesota Press, 1984.

Cambridge Companion to Dostoevskii. Ed. by William J.

Leatherbarrow. Cambridge : Cambridge University Press, 2002. Derrida, Jacques: Monolingualism of the Other or The Prosthesis of Origin. Stanford, California: Stanford University Press, 1998.

Derrida, Jacques: Acts of Literature. Edited by Derrek Attridge. New York: Routledge, 1992.

Derrida, Jacques. Aporias. Editors Werner Hamacher and David E.

Wellbery. Stanford: Stanford University Press, 1993.

Derrida, Jacques. Given Time: I. Counterfeit Money (Chicago and London: The University of Chicago Press, 1994. Translated by 
Peggy Kamuf.

Derrida, Jacques. The Gift of Death. Translated by David Wills. Chicago and London: The University of Chicago Press, 1992.

Derrida's Legacies, Literature and philosophy. Ed. by Simon

Glendinning and Robert Eaglestone. London and New York: Routledge, 2008.

Derrida, Jacques. Positions. Translated and annotated by Alan Bass. Chicago: The University of Chicago Press, 1982.

Derrida, Jacques. Dissemination. Translated, with an Introduction and

Additional Notes, by Barbara Johnson. Chicago, The University of Chicago Press, 1981.

Derrida, Jacques: Of Spirit, Heidegger and the Question. Translated by

Geoffrey Bennington and Rachel Bowlby. Chicago and London: The University of Chicago Press, 1989.

Derrida, Jacques: Writing and Difference, Translated, with an Introduction and Additional Notes, by Alan Bass. Chicago: The University of Chicago Press, 1978.

Derrida, Jacques: Psyche, Inventions of the Other, vol. I, Ed. by Peggy

Kamuf and Elizabeth Rottenberg. Stanford, California: Stanford University Press, 2007.

Deleuze, Gilles. Différence et répétition. Presses Universitaires de France, 1968.

Dostoyevsky, Fyodor M. The Brothers Karamazov. Translated with the Introduction and Notes by David McDuff. London: Penguin Books, 2003. Deconstruction and Criticism. Harold Bloom. Jacques Derrida. Geoffrey H. Hartman. J. Hillis Miller. London, New York: Continuum, 2004.

Eliot, T. S. The Complete Poems and Plays 1909 - 1950. New York: Harcourt Brace and Company, 1952.

Eco, Umberto: The Role of the Reader, Explorations in the Semiotics of Texts. Bloomington: Indiana University Press, 1984.

Eco, Umberto: On Literature, Translated from the Italian by Martin McLaughlin. New York: Harcourt, INC. 2004.

Freud, Sigmund. Totem and Taboo. The Origins of Religion, trans. James Strachey. Pelican Freud Library, vol. 13. Harmondsworth: Penguin, 1985.

Heidegger, Martin. Unterwegs zur Sprache. Verlag Güther Neske, Pfullingen, fünfte Auflage, 1975.

Heidegger, Martin. Contributions to Philosophy (Of the Event). Bloomington and Indianapolis: Indiana University Press, Heidegger, Martin. Beiträge zur Philosophie (Vom Ereignis), 
Gesamtausgabe, band 65, Herausgegeben von Friedrich-Wilhelm von Herrmann (Frankfurt am Main, Satz und Druck: Poeschel \& SchulzSchomburgk, 1989).

Horrocks, Roger: Freud Revisited, Psychoanalytic Themes in the Postmodern Age. London: Palgrave, 2001.

Lacan, Jacques: My Teaching. Translated by David Macey. London.

New York: Verso, 2008.

Lacan, Jacques: Ecrits. A Major New Translation by Bruce Fink. New

York. London: W. W. Norton and Company.

McKenna, Andrew J. Violence and Difference, Girard, Derrida, and

Deconstruction. Urbana and Chicago: University of Illinois Press, 1992.

Patočka, Jan. Philosophy and Selected Writings. Chicago: University of

Chicago Press, 1989. 2012.Translated by Richard Rojcewicz and Daniela

Vallega-Neu.

Questioning God. Edited by John D. Caputo, Mark Dooley, and Michael

J. Scanlon. Bloomington and Indianapolis: Indiana University

Press, 2001.

Religion. Ed. by J. Derrida and Gianni Vattimo. Stanford, California:

Stanford University Press, 1998.

Shakespeare, William. "Sonnets and 'A Lover's Complaint'". The

Oxford Shakespeare, The Complete Works. General editors Stanley Wells

and Gary Taylor. Oxford: Clarendon Press, 1988.

Tolstoy, Lev N. Childhood, Boyhood, Youth. Translated by Rosemary

Edmonds. Penguin Books Limited, 1964.

The Politics of Deconstruction, Jacques Derrida and the Other of Philosophy. Ed. by M. McQuillan. London: Pluto Press, 2007...

\section{NA POČETKU VEĆ BI NASILJE: PRAVDA I ZAKON BRAĆA KARAMAZOV FJODORA DOSTOJEVSKOG}

U realističkom romanu „Braća Karamazov” otvaraju se kritička pitanja vezana za modernističku poetiku. $U$ narativu se odnose na pitanje religije, prava, zakona i poretka. Ona se tumače kako na opštem tako i na pojedinačnom pojmovnom planu čineći od romana komleksni sistem narativnih sekvenci. U sekvenci koja se vezuje za lik Ivana Karamazova postavlja se pitanje fikcije u fikciji, pisanja i stvaranja, ponavljanja uloga autora i spektalnih likova u priči ali i liku Ivana Karamazova. Kada smo pomenuli da su pitanja modernističko-kritička, mislili smo na intenzitet njihovog pojavljivanja. Modernizam uspostavlja problemsku situaciju same umetnosti, postavljajući u obliku metakvaliteta osnove 
umetničkih dela, pitanje o umetničkom kvalitetu ali i njenoj pripadajućoj oblasti. Postavlja se pitanje koja je osnova književnog. Književni oblici se savijaju autoreferencijalno ka sebi, ka čitavoj umetnosti i kulturi, da bi se opet lučno izvili i izrazili stvarnost. Modernistička dela u načinu svog stvaranja upućuju pitanje čitaocima da li su sve književne teme, legitimno književne ili se književnost može baviti „svakom” temom. Ta pitanja se pojavljuju s obzirom da se umetnost autoreferencijalno savila ka čitavoj kulturi i umetnosti za svekolika pitanja koja su se obrađivala u posebnim naučnim oblastima. Stoga se ponekad kaže da su književna dela filozofska, psihološka, itd. Međutim, to se odnosi na čitav književni poredak, ali u slučaju navedenog narativa pitanja su do te mere složena i u njihovu složenost je upleteno i pitanje o samom statusu književnog. Ono se odnosi na narativne i diskursivne strategije u kojima lik Ivana Karamazova razrađujući sopstveno delo unutar već postojeće narativne strukture uspostavlja pitanje fikcionalnosti narativa „Braća Karamazov”. U prepletnom tkanju jezičkog i strukturalno-semantičkog nivoa, posmatramo kako se izgrađuje lik Ivana Karamazova, ali i promišljaju pitanja vezana za religiju, psihologiju, filozofiju itd. Na jezičkom nivou uočava se pitanje jezika i njegove upotrebe u religiji koje prerasta $u$ pitanje jezika kao takvog, monolingvističkog ili monolingvističke proteze jer se jezik može posmatrati kao polje upotrebe drugih. Jezički nivo se produbljuje i prepliće sa strukturalnim i semantičkim na kojima posmatramo izgradnju $i$ istovremenu nemogućnost izgradnje identiteta Ivana Karamazova, koji se u oblasti pojmova zakona i oproštaja nalazi u aporijskom stanju. Ivan Karamazov živi u sopstvenom egzilu i ne može da potvrdi pripadnost ni sebi ni drugima. Pripadnost se odnosi na prikladnost i svojstvenost, posedovanje (property/proper/own) koje se ogleda u jeziku, religiji, pravu, zakonu itd. Relacije čitave egzistencijalne problematike lika Ivana Karamazova, a i fikcionalne strukture koja se odnosi na narativne linije njegove priče se uspostavljaju i u uspostavljanju, promišljaju i pomeraju, pomerajući i izmeštajući čitavu narativnu strukuturu van samog romana. U narativnim linijama prepletena stuktura koja prati Ivanovu priču prepliće se sa diskursivnim strategijama likova njegove porodice, ali i širim okvirom detektivske priče koja leži u obrascu ovog romana. Stoga se može govoriti ne samo o fikciji u fikciji, autoreferencijalnosti u Ivanovoj priči već o multilinearnosti i multireferencijalnosti čitavog narativa, a pitanja koja se postavljaju data su čitaocima da ih razreše i promišljaju o njima. Pojam događaja koji je uspostavljen kao konstitutivno načelo realističkog romana ovde je predstavljen i na modernistički način koji kritički osvetljava sopstvenu narativnu osnovu ali i promišlja o svekolikim pitanjima kulture i civilizacije. Ivan Karamazov ulazi u polje 
ne/mogućeg jer je oproštaj zaustavljen, a sa njim i pitanja greha, iskupljenja, ispovesti, ispaštanja, spasenja itd. Oproštaj je ne-moguć, ali i moguć u fikcionalnosti narativa u kome su odgovori prepušteni imaginaciji i znanju čitaoca. Uloge model čitaoca su brojne kao i narativne strukture koje istovremeno postavljaju pitanja o sebi i dok to čine postavljaju se pitanja ne samo na religijskim, filozofskim, psihološkim, zakonodavnim, već i mnogim drugim poljima. Narativ pratimo na dve šine, ali se one u krovnim pojmovima jezika, identiteta, greha, iskupljenja, oproštaja, zakona, događaja ukrštaju na više načina, te moramo dobro paziti za koji voz i koju putanju smo platili kartu.

Ključne reči: višestrukost narativnih struktura i diskursivnih strategija, preplet strukturalno-semantičko-jezičkih nivoa, fikcija u fikciji, monolingvizam, aporija, autoreferencijalnost, spektalni likovi, oproštaj, greh, iskupljenje, zakon i pravda, identitet pojedinca, lika, narativa. 